\title{
Keberlanjutan Pengelolaan Wisata Bahari di Pulau Pari, Kabupaten Kepulauan Seribu
}

\section{(Management Sustainability of Marine Tourism in Pari Island, Kepulauan Seribu District}

\author{
Neksidin $^{1 *}$, Achmad Fahrudin $^{2}$, Majariana Krisanti ${ }^{2}$ \\ (Diterima Maret 2019/Disetujui Maret 2021)
}

\begin{abstract}
ABSTRAK
Pulau Pari memiliki sumber daya alam yang cukup besar sehingga berpotensi berdampak sosial-ekonomi bagi masyarakat setempat jika dikelola dengan baik. Pengelolaan Pulau Pari saat ini memang terfokus pada pengelolaan wisata bahari, yang sudah berlangsung cukup lama dan telah berdampak sangat nyata pada sektor ekonomi di Pulau Pari. Di sisi lain kegiatan tersebut dikhawatirkan pula mengganggu ekologi sehingga untuk mencapai pengelolaan yang berkelanjutan, diperlukan pengawasan dan pengaturan yang baik agar potensi yang dimiliki tetap terjaga. Tujuan penelitian ini ialah mengevaluasi status keberlanjutan sosial ekonomi dan ekologi sebagai dampak dari pengembangan wisata bahari di Pulau Pari. Data dikumpulkan melalui wawancara secara mendalam kepada masyarakat di Pulau Pari dan data primer dan sekunder terkait sosial-ekologi. Untuk menilai tingkat keberlanjutan pada setiap dimensi, dilakukan analisis multidimensional scaling, sehingga diperoleh dua dimensi yang memiliki nilai di bawah $75 \%$, yaitu dimensi kelembagaan dengan nilai $27,3 \%$ (buruk) dan dimensi infrastruktur dengan nilai $73,3 \%$ (cukup). Adapun 3 dimensi lainya, yakni dimensi ekologi, ekonomi, dan sosial menunjukkan nilai yang masuk kategori berlanjut, yaitu $>75 \%$ sehingga sangat mendukung keberlanjutan pengelolaan usaha wisata bahari.
\end{abstract}

Kata kunci: dampak pengembangan wisata bahari, keberlanjutan pengelolaan, Sosial-Ekologi Pulau Pari, wisata bahari

\begin{abstract}
Pari Island has considerable natural resource potential, so that it has the potential to have socio-economic impacts on the local community if managed properly. The current management of Pari Island is indeed focused on the management of marine tourism, and this activity has been going on for a long time and has had a very significant impact on the economic sector in Pari Island. On the other hand, marine tourism activities in Pari Island are feared to have an impact on the ecological sector, so that to achieve sustainable management, good supervision and control is needed so that its potential is maintained. The purpose of this research is to see the status of socio-economic and ecological sustainability as a result of the development of marine tourism in Pari Island. The data were collected through in-depth interviews with the people of Pari Island, apart from that the data were also obtained from primary and secondary data related to socio-ecology. To assess the level of sustainability in each dimension, a Multidimensional Scaling (MDS) analysis was carried out, in order to obtain two dimensions that had a value below $75 \%$, namely the institutional dimension which had a value of $27.3 \%$ (bad), and the infrastructure dimension which had a value. $73.3 \%$ (Enough). Meanwhile, the other 3 dimensions, such as the ecological, economic, and social dimensions, show that the value is in the continuous category, namely $>75 \%$ so that it is very supportive of the sustainability of marine tourism business management.
\end{abstract}

Keywords: impact of marine tourism development, marine tourism, Pari Island, sustainable management

\section{PENDAHULUAN}

Pengelolaan pulau-pulau kecil di Indonesia harus sedapat-dapatnya dikelola dengan mempertimbangkan segi keberlanjutan, sehingga tidak saling

1 Jurusan IImu Perikanan, Fakultas Pertanian, Universitas Bina Insan Lubuklinggau, Jl. HM Soeharto No.Kel, Lubuk Kupang, Kota Lubuklinggau, Sumatera Selatan 31626

2 Departemen Manajemen Sumberdaya Perairan, Fakultas Perikanan dan IImu Kelautan, Institut Pertanian Bogor, Kampus IPB Darmaga, Bogor 16680

* Penulis Korespondensi:

Email: neksidin@univbinainsan.ac.id merugikan semua aspek lain yang terlibat, baik itu aspek sosial, ekonomi, budaya masyarakat, dan ekologi. UU RI No 1 tahun 2014 menyatakan bahwa pengelolaan wilayah pesisir dan pulau-pulau kecil meliputi perencanaan, pemanfaatan, pengawasan, dan pengendalian sumber daya pesisir dan pulaupulau kecil antarsektor, yaitu antara pemerintah pusat dan pemerintah daerah, antara ekosistem darat dan laut, serta antara ilmu pengetahuan dan manajemen guna meningkatkan kesejahteraan masyarakat. Pengembangkan pulau-pulau kecil yang berbasis konservasi dan masyarakat merupakan wujud nyata dalam upaya pengelolaan sumber daya alam demi keberlanjutan pemanfaatan (Anwar 2011). 
Pengelolaan pulau-pulau kecil dimaksudkan untuk memberdayakan serta meningkatkan kemampuan kawasan dalam mengelola potensi perikanan dan kelautan secara terpadu dan menyeluruh, melalui kemampuan daerah, partisipasi publik, dunia usaha, serta dukungan pemerintah. Terkait dengan strategi pengelolaan pulau-pulau kecil, saat ini Pulau Pari sepenuhnya dikelola oleh masyarakat dengan metode dan strategi yang masih kurang sempurna, bahkan orientasi pengelolaannya masih dititikberatkan pada peningkatan sektor ekonomi semata, tanpa mempertimbangkan keberlanjutan segi sosial dan ekologi. Pengelolaan seperti ini dikhawatirkan akan menurunkan kualitas sumber daya alam dan lingkungan yang juga dapat memengaruhi kualitas sumber daya manusia secara umum.

Pengembangan Pulau Pari melalui wisata berkelanjutan membutuhkan intergrasi dari dua komponen biofisik, termasuk lingkungan hidup dan prasarana, serta sosial-ekonomi, yaitu isu-isu yang berkaitan dengan sikap lokal, persepsi, dan perubahan kualitas hidup akibat dampak wisata. Keduanya memiliki batasan alam dalam kegiatan ekowisata, jika melebihi batas ini melalui pembangunan yang tidak direncanakan pasti akan mengarah ke degradasi lingkungan atau konflik sosial (Wong 1998). Berangkat dari masalah tersebut, perlu dikaji dimensi apa saja yang berpengaruh cukup besar pada keberlanjutan pengelolaan Pulau Pari, serta bagaimana strateginya agar pengelolaan wisata baharinya tetap terjaga dan berkelanjutan.

Tujuan penelitian ini ialah (1) menentukan status keberlanjutan pengelolaan wisata bahari berdasarkan dimensi sosial, ekonomi, ekologi, kelembagaan, dan infrastruktur di Pulau Pari dan (2) menentukan strategi pengelolaan yang tepat dan berkelanjutan.

\section{METODE PENELITIAN}

\section{Waktu dan Lokasi Penelitian}

Penelitian ini dilaksanakan pada bulan FebruariApril 2015 di Pulau Pari, Kecamatan Kepulauan Seribu Selatan, Kabupaten Kepulauan Seribu, Provinsi DKI Jakarta. Lokasi penelitian dipilih berdasarkan data dan informasi yang memperlihatkan perkembangan pengelolaan Pulau Pari untuk kawasan wisata bahari yang sangat pesat sehingga dikawatirkan terjadi degradasi lingkungan yang mengakibatkan dampak besar bagi keberlanjutan pengelolaan wisata bahari.

\section{Prosedur Pengumpulan Data}

Sampel dikumpulkan dengan cara purposif, yakni memilih penduduk lokal yang menjadi pelaku usaha di sektor wisata bahari. Data ekologi mengacu pada data primer dan data sekunder dari penelitian sebelumnya yang terkait dengan kondisi kualitas air dan kondisi ekosistem lainnya. Data sosial dalam penelitian ini diperoleh dari masyarakat dan wisatawan. Data dari responden masyarakat dimaksudkan untuk menggali persepsi tentang wisata bahari, sementara data dari responden wisatawan adalah untuk menghitung nilai manfaat ekonomi. Teknik pengambilan responden adalah non-probability sampling; responden masyarakat dipilih secara purposif, sedangkan responden wisatawan secara accidental sampling. Data infrastruktur diperoleh dari data primer dan data sekunder yang terkait dengan jumlah fasilitas wisata termasuk bangunan penunjang seperti homestay, teknik pengolahan sampah, dan pusat Kesehatan masyarakat. Data kelembagaan diperoleh melalui wawancara langsung dengan pemerintah setempat dan beberapa tokoh masyarakat yang terlibat dalam kegiatan wisata bahari. Data primer dimaksudkan guna menunjang data yang diperoleh di lapangan, yang selanjutnya dibandingkan untuk melihat perubahan yang terjadi akibat aktivitas wisata bahari, termasuk perubahan aturan baik yang tertulis (peraturan desa dan peraturan daerah) maupun yang tidak tertulis seperti aturan adat (kearifan lokal).

\section{Analisis Data}

Keberlanjutan pembangunan kawasan Pulau Pari dianalisis melalui beberapa tahap, yaitu tahap penentuan atribut sistem pengembangan kawasan berkelanjutan yang mencakup 5 dimensi, yaitu dimensi ekologi, ekonomi, sosial, kelembagaan, dan infrastruktur. Tahap penilaian setiap atribut dalam skala ordinal didasarkan pada kriteria keberlanjutan setiap dimensi, analisis ordinasi yang berbasis metode multidimensional scaling (MDS), penyusunan indeks, dan status keberlanjutan pengembangan kawasan pada kondisi terkini yang dikaji baik secara umum maupun pada setiap dimensi (Fauzi \& Anna 2002). Data yang dikumpulkan terkait penentuan status keberlanjutan pembangunan kawasan Pulau Pari, meliputi data potensi sumber daya alam, dinamika penduduk, tenaga kerja, penggunaan lahan, dan sarana-prasarana wilayah. Teknik pengumpulan data adalah observasi, wawancara/kuesioner, dan dokumentasi.

Tahap selanjutnya adalah perhitungan, yang mencakup perhitungan data sekunder dan data primer yang selanjutnya setiap atribut diberi skor atau peringkat yang mencerminkan keberlanjutan dari dimensi pembangunan yang bersangkutan. Berikutnya, skor tersebut akan menunjukkan nilai "buruk" di satu ujung dan nilai "baik" di ujung yang lain (Alder et al. 2000). Nilai "buruk" mencerminkan kondisi yang paling tidak menguntungkan sistem pengembangan kawasan berkelanjutan. Sebaliknya, nilai "baik" mencerminkan kondisi yang paling menguntungkan. DI antara kedua ekstrem nilai ini terdapat satu atau lebih nilai antara, bergantung pada jumlah peringkat pada setiap atribut.

Peringkat disusun berdasarkan urutan nilai terkecil ke nilai terbesar baik secara kuantitatif maupun kualitatif dan bukan berdasarkan urutan nilai dari yang terburuk ke nilai yang terbaik. Penentuan nilai skor baik atau buruk pada metode analisis keberlanjutan ini 
berkaitan dengan persepsi sehingga suatu atribut harus dilihat terlebih dahulu dari persepsi apa.

Data yang diperoleh kemudian dianalisis dengan menggunakan peranti lunak Rapfish (Rapid Appraisal for Fisheries), yakni metode multidisiplin untuk mengevaluasi perbandingan pengelolaan wisata berkelanjutan berdasarkan jumlah atribut yang banyak tetapi mudah dinilai. Dalam analisis Rapfish, setiap data yang diperoleh diberi skor yang menunjukkan status sumber daya tersebut. Hasil statusnya menggambarkan keberlanjutan di setiap aspek yang dikaji dalam bentuk skala 0 sampai $100 \%$. Jika sistem yang dikaji mempunyai indeks lebih dari 75\%, maka pengembangan tersebut berkelanjutan; sebaliknya jika kurang dari $75 \%$ maka sistem tersebut tidak berkelanjutan (unsustainable). Menurut Susilo (2003), status keberlanjutan dibagi ke dalam 4 kategori, yakni 0-25 (Buruk), 26-50 (Kurang), 51-75 (Cukup), dan 76-100 (Baik).

Pada tahap selanjutnya, dilakukan analisis sensitivitas untuk menentukan atribut yang paling sensitif berkontribusi pada indeks keberlanjutan di lokasi penelitian. Pengaruh dari setiap atribut dilihat dalam bentuk perubahan root mean square (RMS) ordinasi, khususnya pada sumbu $X$ atau skala keberlanjutan (Alder et al. 2000). Semakin tinggi nilai perubahan RMS akibat hilangnya suatu atribut tertentu, semakin besar pula peranan atribut tersebut dalam pembentukan nilai indeks keberlanjutan pada skala keberlanjutan; dengan kata lain, semakin sensitif atribut tersebut dalam menentukan keberlanjutan pengembangan kawasan di lokasi studi.

\section{HASIL DAN PEMBAHASAN}

\section{Analisis MDS untuk Wisata Bahari}

Analisis MDS) bertujuan mengevaluasi keberlanjutan pengelolaan wisata bahari dari lima aspek, yaitu aspek sosial, ekonomi, ekologi, kelembagaan, dan infrastruktur yang ada di Pulau Pari. Setiap dimensi akan memberikan atribut yang dianggap berpengaruh pada keberlanjutan pengelolaan pada dimensinya masing-masing.

\section{Dimensi Sosial}

Mayoritas masyarakat Pulau Pari berpendidikan rendah(67\%), yakni hanya sampai sekolah dasar (SD), SMP 8\%, SMA 17\%, dan sisanya perguruan tinggi $2 \%$. Untuk partisipasi anggota keluarga dalam usaha wisata bahari mayoritas (69\%) responden mengatakan bahwa ada 2-3 anggota keluarga yang terlibat langsung dalam membantu usaha, dan $23 \%$ mengatakan lebih dari 3 anggota keluarga yang terlibat dalam usaha, sedangkan sisanya sebanyak $8 \%$ menyatakan tidak ada anggota keluarga yang terlibat . Dari tingkat penerimaan masyarakat terhadap wisatawan, kebanyakan responden sangat menerima (69\%), menerima (29\%), sisanya tidak menerima (1\%). Untuk atribut alternatif usaha lain, mayoritas masyarakat memiliki 1-2 usaha (38\%), memiliki >2 usaha $(27 \%)$, dan sisanya (35\%) tidak mempunyai usaha lain selain mengandalkan wisata sebagai sumber mata pencaharian mereka. Terkait perubahan sikap atau sosial masyarakat Pulau Pari, kebanyakan responden (76\% dari 131 responden) mengatakan tidak terjadi perubahan dari segi sosial masyarakat, sedangakan sisanya (24\%) mengemukakan terjadi perubahan sosial masyarakat seperti kurangnya sosialisasi antarmasyarakat Pulau Pari. Kondisi tersebut menurut mereka dipengaruhi oleh makin padatnya kegiatan masyarakat karena meningkatnya jumlah wisatawan yang berkunjung, sehingga waktu untuk bersama keluarga dan masyarakat sekitar berkurang. Perihal konflik antarpengelola wisata, 70\% responden mengatakan tidak ada konflik selama adanya wisata, dan $30 \%$ lainnya menyatakan terjadi konflik walaupun jarang dan hanya terjadi setahun sekali. Untuk atribut mengenai pengaruh wisatawan pada interaksi antarpenduduk, tidak ada perubahan, $75 \%$ responden mengatakan bahwa setelah ada kegiatan wisata, masyarakat lebih banyak waktu untuk bersosialisasi dengan masyarakat lainnya.

Dimensi sosial merupakan salah satu faktor yang sangat besar pengaruhnya pada usaha wisata bahari. Gambar 1 menunjukkan bahwa ada 7 atribut yang dianggap berpengaruh pada keberlanjutan usaha wisata bahari dan dianggap sensitif, yakni interaksi antarpenduduk, konflik antarpengelola wisata, perubahan sikap dan perilaku masyarakat, alternatif usaha lain, tingkat penerimaan masyarakat terhadap wisatawan, partisipasi keluarga dalam usaha wisata bahari, dan tingkat pendidikan masyarakat Pulau Pari. Semua atribut ini merupakan faktor pengungkit sehingga untuk keberlanjutan suatu usaha wisata bahari semua atribut tersebut harus lebih diperhatikan dan menjadi fokus dalam suatu pengelolaan wisata berkelanjutan.

\section{Dimensi Ekonomi}

Dimensi ekonomi merupakan salah satu dari 5 dimensi yang dianalisis untuk mengevaluasi keberlanjutan pengelolaan wisata Pulau Pari. Dimensi ini merupakan tolok ukur keberlanjutan suatu usaha. Dari dimensi ekonomi ada beberapa atribut yang dimasukkan dan dianggap memengaruhi keberlanjutan ekonomi dari usaha wisata bahari. Lima atribut yang dianggap berpengaruh ialah (1) pendapatan rumah tangga (skor 1: pendapatan masyarakat setara upah minimum regional (UMR), (2) ketersediaan modal usaha (skor 2: 51\% merupakan modal sendiri, dan sisanya menunggu bantuan dari pemerintah), (3) analisis usaha wisata bahari: dari analisis $R / C$ diperoleh nilai sangat menguntungkan atau $\mathrm{R} / \mathrm{C}=2$ dan diberi bobot 2, (4) Penyerapan tenaga kerja: 67\% reponden menyatakan sangat besar pengaruh penyerapan tenaga kerja oleh usaha wisata bahari (skor 2), (5) Kontribusi sektor wisata terhadap pendapatan masyarakat: $79 \%$ responden mengatakan terjadi perubahan pendapatan, yakni dari yang semula 
pendapatan hanya diperoleh dari budi daya rumput laut dengan perputaran uang yang cukup lama, sekarang hanya dalam waktu \pm 1 pekan masyarakat bisa mendapatkan keuntunggan yang lebih besar sehingga dapat menutup kebutuhan rumah tangga, (6) Untuk atribut terkait kesempatan bekerja, $>50 \%$ masyarakat yang awalnya merupakan pengangguran, kuli bangunani, dan buruh pabrik sekarang menjadi pengelola wisata, dan hampir semua masyarakat Pulau Pari terlibat dalam usaha wisata tersebut, (7) Untuk iklim investasi memang telah dirasakan ada tetapi masih sangat terbatas sehingga kebutuhan wisatawan belum terpenuhi.

Dimensi ekonomi pada Gambar 2 menunjukkan bahwa nilai ungkit atribut yang diperoleh rata-rata di atas 1,5 atau memiliki nilai ungkit yang sensitif, yaitu iklim investasi, kesempatan bekerja, kontribusi sektor wisata pada pendapatan usaha, penyerapan tenaga kerja, analisis pendapatan usaha, ketersediaan modal usaha, dan pendapatan rumah tangga. Ketujuh atribut tersebut merupakan faktor yang dianggap sensitif untuk keberlanjutan pengelolaan sehingga harus ditingkatkan dan diperbaiki lagi agar pengelolaan dapat lebih berkelanjutan. Pengelolaan wisata bahari di Pulau Pari saat ini memang terfokus pada peningkatan ekonomi masyarakat, sehingga dengan memanfaatkan kondisi alam yang telah ada, masyarakat dapat memperoleh keuntungan dari jasa wisata. Oyewole (2001) berpendapat bahwa spesialisasi di bidang jasa wisata memiliki dampak positif yang cukup kuat terhadap kinerja ekonomi.

Pada proses pertumbuhan ekonomi, faktor ukuran suatu kawasan juga sering menjadi pembatas dalam mencapai skala ekonomi tertentu karena terbatasnya berbagai kegiatan dasar ekonomi yang dapat dilakukan (Read 2001). Pembatas ini berkaitan dengan ukuran pasar, sumber daya, tenaga kerja, dan kekuatan modal wilayah sempit untuk menyongsong ekonomi global serta mencapai skala ekonomi yang cukup besar. Lebih lanjut Venegas and Croes (2003) menambahkan bahwa hubungan yang kuat antara wisata dan kinerja ekonomi yang wilayahnya lebih sempit bukan menjadi alasan terhambatnya kinerja pertumbuhan ekonomi di suatu wilayah.

\section{Dimensi Ekologi}

Dimensi ekologi merupakan salah satu aspek yang cukup memengaruhi aktivitas wisata, Mengingat wisata Pulau Pari merupakan wisata yang berorentasi pada panorama alam laut, maka jika kualitas air atau

Pengungkit Atribut

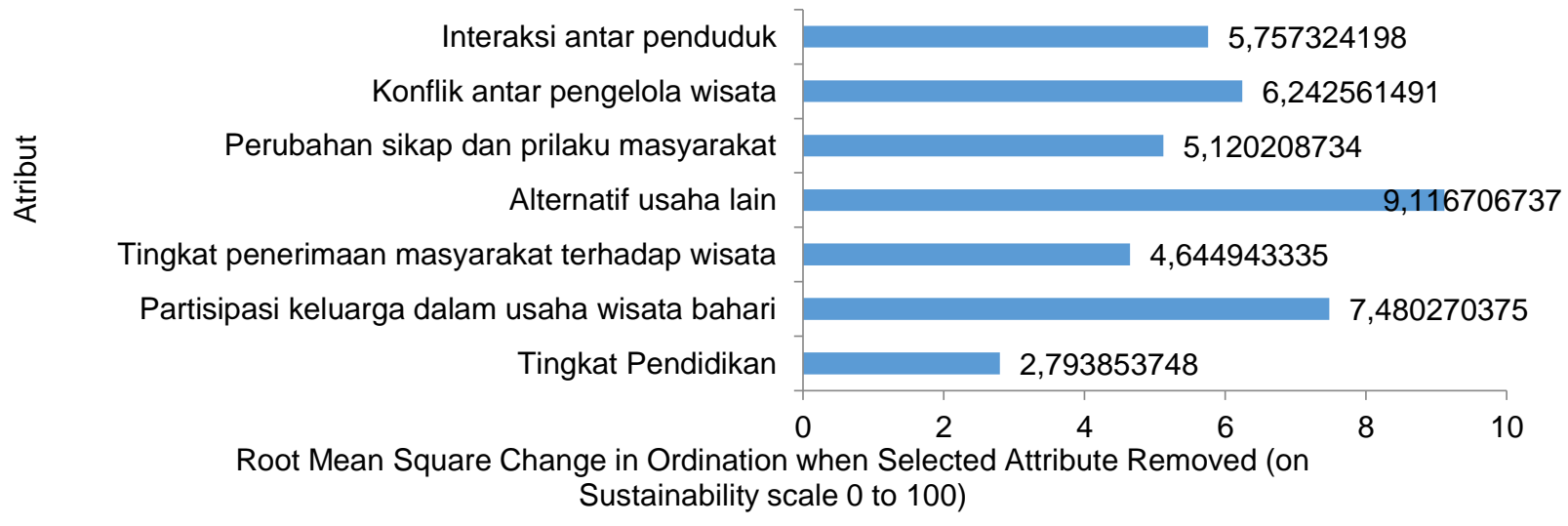

Gambar 1 Atribut sosial yang menjadi faktor pengungkit keberlanjutan wisat bahari Pulau Pari.

Pengungkit Atribut

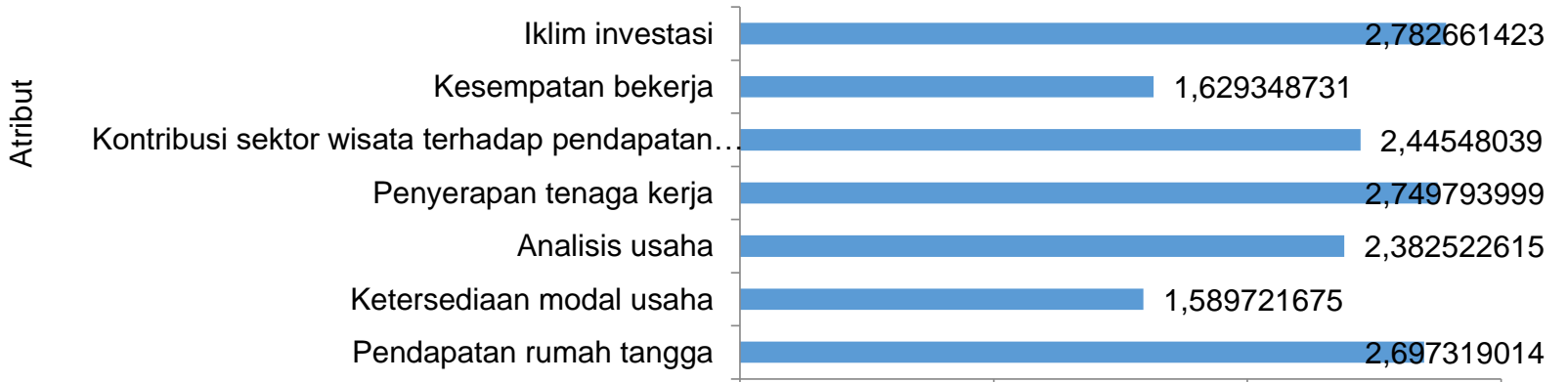

Root Mean Square Change in Ordonation when Seledted Attribute Rem@ved (on 3 Sustainability scale 0 to 100 )

Gambar 2 Atribut ekonomi yang menjadi faktor pengungkit keberlanjutan wisata bahari Pulau Pari. 
ekologinya rusak, wisata di pulau ini mungkin tidak akan berkelanjutan. Berdasarkan analisis daya dukung, nilainya sangat sesuai untuk kategori wisata snorkling dan wisata pantai sehingga skor yang diperoleh adalah 2. Untuk ketersediaan air bersih untuk MCK, setiap rumah memiliki sumber air berupa air sumur yang dapat digunakan untuk kebutuhan seharihari. Lain halnya dengan kebutuhan air untuk masak dan minum, masyarakat mengandalkan pasokan air tawar (galon) yang berasal dari Tangerang dan Jakarta sehingga kebutuhan air untuk masak dan minum terbatas. Setelah ada aktivitas wisata bahari terjadi perubahan pengelolaan sampah yang sangat nyata, masyarakat menjadi cenderung lebih peka akan keberadaan sampah. Upaya untuk mencegah peningkatan jumlah sampah ialah dengan membentuk tim pengelola sampah yang khusus bertugas membersihkan sampah setiap pagi sehingga tidak terjadi tumpukan sampah berlebihan. Tingkat kecemaran perairan Pulau Pari menggambarkan tingkat kebutuhan oksigen hayati (BOD) masih sesuai dengan baku mutu lingkungan sehingga belum berbahaya untuk aktivitas wisata bahari; secara keseluruhan skor yang diperoleh ialah 2, atau sangat sesuai.

Gambar 3 memperlihatkan bahwa semua atribut dari dimensi ekologi dianggap sensitif untuk keberlanjutan wisata bahari, yakni tingkat kecemaran perairan, pengelolaan sampah, ketersediaan air bersih untuk konsumsi, ketersediaan air bersih untuk MCK, serta daya dukung wisata untuk kategori wisata pantai dan wisata snorkling. Semua atribut tersebut merupakan faktor yang dianggap sensitif terhadap keberlanjutan pengelolaan wisata bahari jika ditinjau dari dimensi ekologi, oleh karena itu jika pengelola wisata bahari menginginkan keberlanjutan maka atribut tersebut merupakan faktor yang harus dipertimbangkan dalam pengelolaannya.

\section{Dimensi Infrastruktur}

Dimensi infrastruktur merupakan dimensi yang cukup berpengaruh terhadap keberlanjutan usaha dan aktivitas wisata Pulau Pari, bahkan dianggap sebagai salah satu faktor yang memengaruhi peningkatan jumlah wisatawan, sehingga dikhawatirkan akan berdampak pada dimensi sosial dan ekologi. Bbeberapa atribut yang dianggap memengaruhi keberlanjutan pengelolaan ialah sarana dan prasarana pasar, sarana dan prasarana kesehatan, dan ketersediaan rambu penunjuk daerah wisata. Ketiga atribut tersebut mendapat skor 1 yang berarti keberadaan dari atribut tersebut masih terbatas, sedangkan untuk atribut ketersediaan jalan, sarana listrik, homestay, toilet umum, dan sarana dan prasarana tempat pembuangan sampah sementara, tergolong sangat baik. Keberadaan infrastruktur tersebut sudah sangat memadai sehingga diberi skor 2 yang merupakan skor tertinggi. Untuk atribut terkait teknologi pengolahan limbah masih belum ada (skor 0). Dengan demikian, untuk keberlanjutan dimensi infrastruktur, atribut tersebut harus dibangun agar dapat menampung limbah yang dihasilkan oleh masyarakat dan wisatawan yang semakin hari semakin meningkat.

Gambar 4 mengungkap bahwa dari semua atribut yang dimasukkan dalam dimensi infrastruktur secara keseluruhan, nilainya masih di atas 1,5 , berarti tergolong sensitif terhadap pengelolaan wisata bahari dari segi infrastruktur. Ini berarti untuk pengelolaan atribut yang dimaksud perlu ditingkatkan lagi dengan banyak perbaikan. Akan tetapi, atribut infrastruktur juga harus tetap mempertimbangkan aspek yang lain sehingga tetap berjalan bersamaan tanpa menurunkan kualitas dimensi-dimensi lainnya.

\section{Dimensi Kelembagaan}

Dimensi kelembagaan merupakan salah satu dimensi yang dianggap berperan cukup besar dalam menentukan keberlanjutan pengelolaan wisata bahari. Tanpa kelembagaan yang baik, tidak mungkin tercapai pengelolaan yang terpadu dan berkelanjutan. Atribut yang dianggap cukup berpengaruh dalam kelembagaan ialah dukungan dari pemerintah daerah (skor 1: rendah), dan kepatuhan pada aturan yang berlaku

Pengungkit Atribut

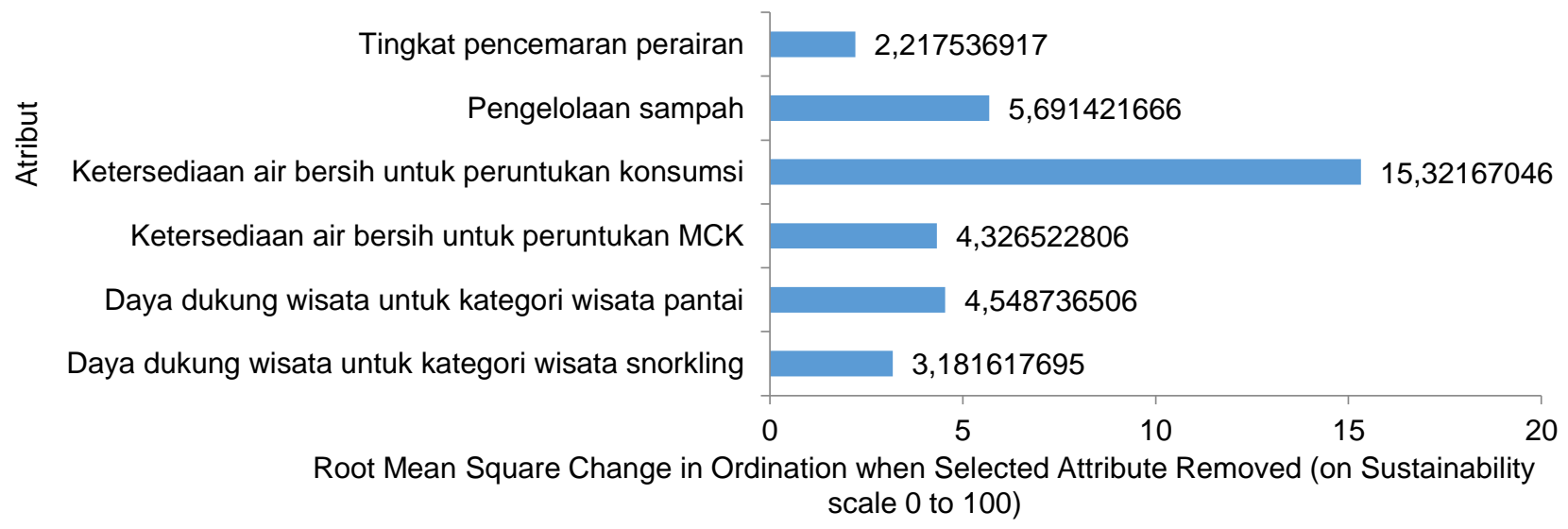

Gambar 3 Atribut ekologi yang menjadi faktor pengungkit keberlanjutan wisata bahari Pulau Pari. 
sesuai dengan ketentuan yang telah ditetapkan oleh pemerintah setempat (skor 1) (Gambar 5). Skor 1 diartikan bahwa atribut tersebut belum sepenuhnya mendapat dukungan dari pemerintah daerah, tetapi di sisi lain ada aturan yang dibuat oleh pemerintah setempat (RW/RT) walaupun kadang-kadang dilanggar oleh wisatawan. Untuk kelembagaan pemodal, peraturan daerah mengenai wisata Pulau Pari, dan kelembagaan yang khusus mengatur kegiatan wisata bahari di pulau ini secara keseluruhan belum ada, sehingga perlu diterbitkan guna menjamin keberlanjutan pengelolaan wisata bahari dari segi kelembagaan.

Dari semua atribut dalam dimensi kelembagaan, semuanya memiliki nilai ungkit di atas 1,5 sehingga semuanya dianggap faktor pengungkit. Oleh karena itu untuk mencapai pengelolaan yang terpadu dan berkelanjutan, kelima atribut tersebut harus menjadi fokus dalam hal pengelolaan agar tercapai pengelolaan wisata bahari yang berkelanjutan dari berbagai segi. Dimensi kelembagaan juga berfungsi mengatur jumlah wisatawan agar tidak melebihi baku mutu lingkungan yang akan mendegradasi ekologi Pulau Pari.

\section{Nilai Ungkit untuk Semua Dimensi Wisata Bahari}

Pada Gambar 6 dari analisis MDS yang menggabungkan antara semua atribut yang dianggap sensitif pada setiap dimensi, terdapat beberapa atribut yang nilainya di atas 1,5 , yang berarti atribut tersebut menjadi faktor pengungkit keberhasilan wisata bahari. Atribut yang dimaksud meliputi ketersediaan peraturan daerah mengenai wisata, sarana listrik, teknik pengolahan limbah, penyerapan tenaga kerja, serta daya dukung wisata untuk kategori wisata pantai. Kelima atribut tersebut merupakan faktor yang dianggap paling sensitif terhadap keberhasilan pengelolaan wisata bahari di Pulau Pari. Oleh karena itu untuk mencapai suatu pengelolaan yang berkelanjutan diperlukan peran serta masyarakat dan

\section{Pengungkit Atribut}

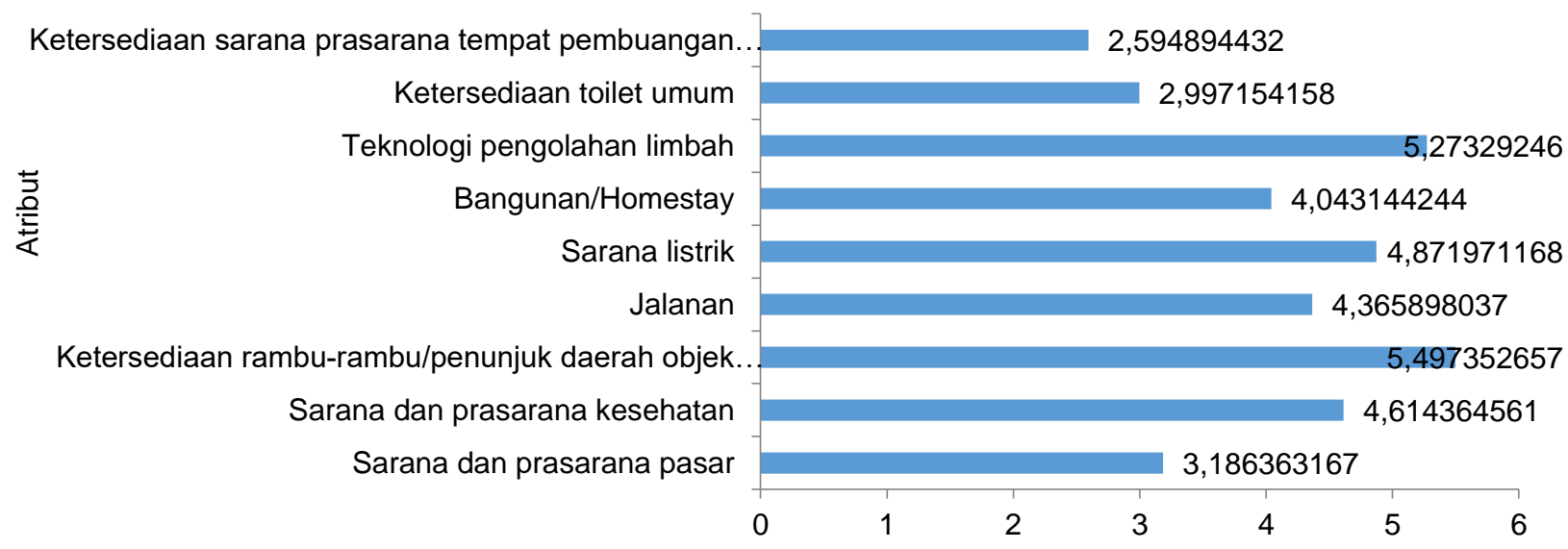

Root Mean Square Change in Ordination when Selected Attribute Removed (on Sustainability scale 0 to 100)

Gambar 4 Atribut infrastruktur yang menjadi faktor pengungkit keberlanjutan wisata bahari Pulau Pari.

Pengungkit Atribut

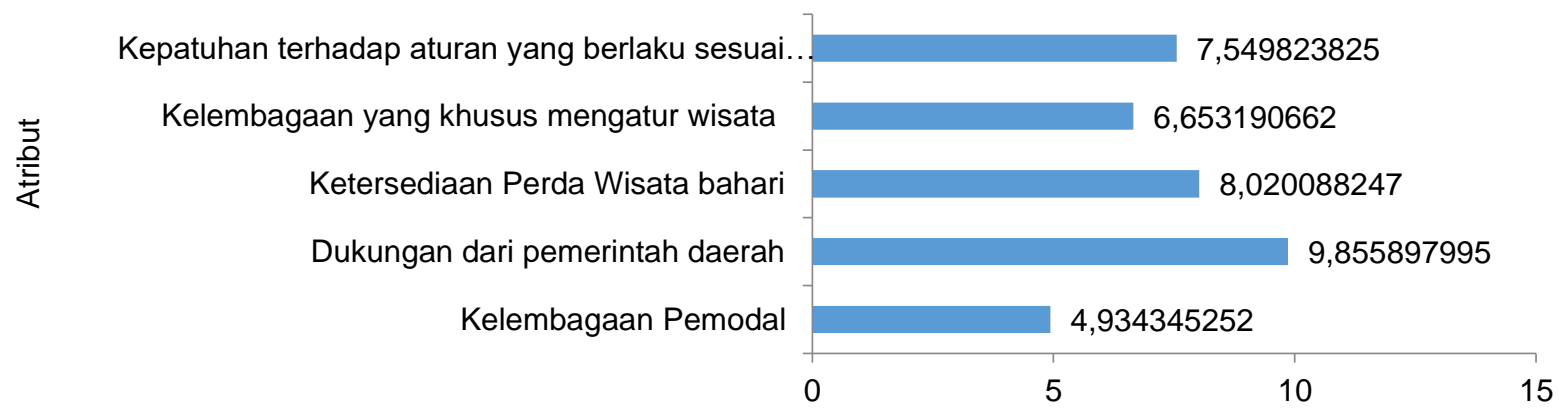

Root Mean Square Change in Ordination when Selected Attribute Removed (on Sustainability scale 0 to 100 )

Gambar 5 Atribut kelembagaan yang menjadi faktor pengungkit keberlanjutan wisata bahari Pulau Pari. 
pemerintah agar semua atribut yang sensitif dan menjadi pengungkit terhadap pengelolaan wisata bahari ditingkatkan.

Wisata bahari merupakan salah satu upaya untuk mengelola pulau-pulau kecil secara berkelanjutan dimana menurut Goosling et al. (2001) bahwa kegiatan wisata yang berkelanjutan merupakan suatu kegiatan dalam memenuhi kebutuhan wisatawan dan juga penduduk sekaligus melindungi dan meningkatkan kesempatan pemanfaatan untuk masa depan. Selanjutnya dalam pengelolaan pulau-pulau kecil bagian yang harus diperhatikan adalah sistem sosialekologi yang ada di sekitar pulau tersebut. Sistem sosial ekologi didefinisikan sebagai sistem yang terpadu dari alam dan manusia dengan hubungan yang timbal balik (Carpenter et al., 2001: Folke et al., 2005). Anderies et al., (2004) mengemukakan bahwa sistem sosial ekologi adalah sebuah sistem dari unit biologi/ekosistem yang berhubungan dan dipengaruhi oleh satu atau lebih sistem sosial, dalam arti membentuk kerja sama dan hubungan saling tergantung dengan yang lain. Dengan demikian sistem sosial-ekologi ini meliputi suatu unit ekosistem seperti wilayah pesisir, ekosistem mangrove, lamun, terumbu karang, pantai yang berasosiasi dengan struktur dan proses sosial yang ada di dalamnya.

\section{Analisis Keberlanjutan Setiap Dimensi}

Dalam analisis MDS pada Gambar 7, terdapat dua dimensi yang masih harus dibenahi agar pengelolaan wisata bahari tetap terjaga dan berkelanjutan. Dimensi yang dimaksud ialah dimensi kelembagaan dengan nilai 27,3\% (Buruk) dan dimensi infrastruktur dengan nilai $73,3 \%$ (Cukup). Dari kedua dimensi tersebut nilai yang diperoleh masih di bawah nilai $75 \%$, yang dimaknai bahwa nilai tersebut tidak berlanjut sehingga diperlukan perbaikan secara menyeluruh agar tidak berdampak pada dimensi yang lain (Tabel 1).

Lain halnya dengan 3 dimensi lainya (ekologi, ekonomi, dan sosial) yang mengindikasikan nilai sebaliknya, yaitu di atas $75 \%$, yang berarti sangat mendukung keberlanjutan pengelolaan usaha wisata bahari. Secara keseluruhan ketiga dimensi tersebut tidak dapat dikatakan sebagai indikator keberlanjutan suatu usaha, karena dalam prinsip analisis MDS setiap dimensi memiliki peran masing-masing dan harus tetap dipertimbangkan antardimensi, termasuk dimensi kelembagaan dan infrastruktur. Oleh karena itu, setiap

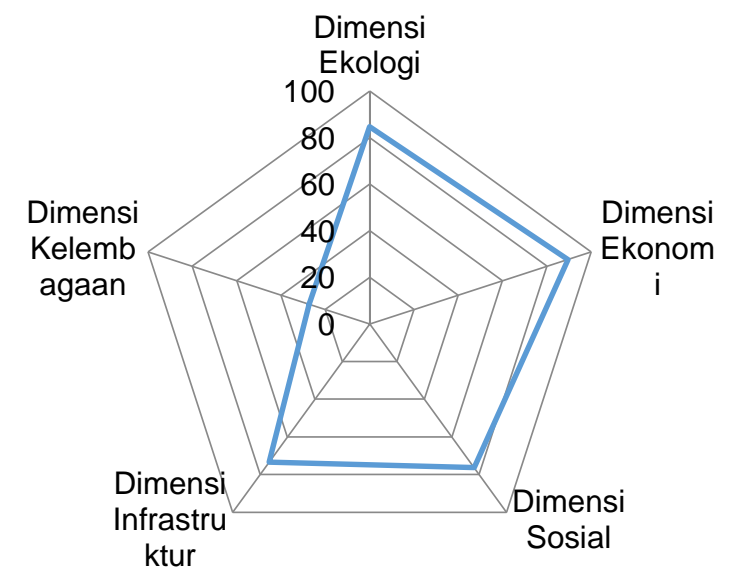

Gambar 7 Nilai keberlanjutan untuk semua dimensi.

Pengungkit Atribut

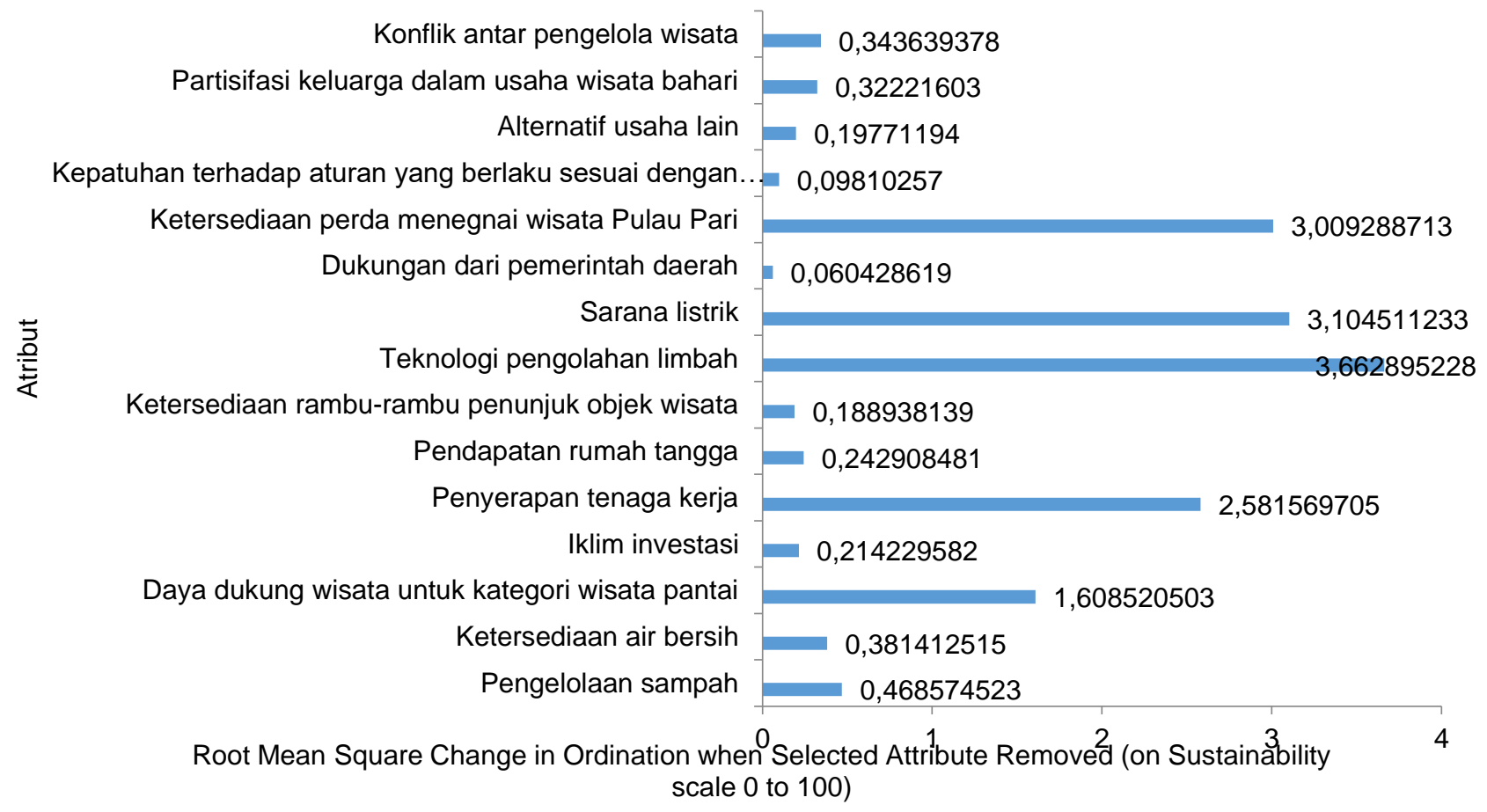

Gambar 6 Analisis pengungkit untuk semua dimensi. 
Tabel 1 Nilai keberlanjutan pada setiap dimensi wisata bahari

\begin{tabular}{lc}
\hline \multicolumn{1}{c}{ Dimensi } & Nilai $(\%)$ \\
\hline Dimensi ekologi & 84,67822 \\
Dimensi ekonomi & 89,49069 \\
Dimensi sosial & 76,33331 \\
Dimensi lifrastruktur & 73,37280 \\
Dimensi kelembagaan & 27,32668 \\
\hline
\end{tabular}

dimensi harus memiliki nilai di atas $75 \%$ agar tercapai suatu pengelolaan yang terpadu dan berkelanjutan dari semua segi. Nilai dimensi kelembagaan memang tergolong sangat rendah bahkan tidak berlanjut, padahal dalam konteks pengelolaan terpadu, dimensi kelembagaan merupakan kontrol yang baik dalam hal pengawasan untuk mencapai keberkelanjutan pengelolaan.

Pengelolaan pulau-pulau kecil harus sedapatdapatnya dikelola dengan prinsip adaptive management. Adaptive management didasarkan pada konsep pembelajaran secara terus menerus dan kolektif yang mengakui ketidakpastian dan memungkinkan penyesuaian saat perencanaan dan pengelolaan strategi (Schianetz et al. 2007). Wong (1998) menjelaskan bahwa pembangunan pulau-pulau kecil melalui wisata berkelanjutan membutuhkan integrasi dari dua komponen biofisik, termasuk lingkungan hidup dan prasarana, serta sosial-ekonomi, isu-isu yang berkaitan dengan sikap lokal, persepsi dan perubahan kualitas hidup akibat dampak wisata. Keduanya memiliki batas alam dalam kegiatan wisata, jika melebihi batas ini melalui pembangunan yang tidak direncanakan, dipastikan akan mengarah ke degradasi lingkungan atau konflik sosial.

\section{KESIMPULAN}

Analisis pengelolaan wisata bahari di Pulau Pari menunjukkan tingkat keberlanjutan yang berbeda pada setiap dimensi, dan terdapat dua dimensi yang tidak berlanjut, yaitu dimensi infrastruktur dan kelembagaan, dengan nilai akumulatif di bawah $75 \%$. Adapun nilai dari dimensi ekologi, ekonomi, dan sosial, berada di atas $75 \%$, sehingga dikategorikan sangat berlanjut. Namun, dalam analisis MDS setiap dimensi sangat berkaitan satu dan lainnya, sehingga untuk mencapai nilai keberlanjutan diperlukan nilai yang berlanjut untuk semua dimensi, termasuk dimensi infrastruktur dan kelembagaan.

Strategi pengelolaan yang direkomendasikan dalam penelitian ini mengacu pada hasil analisis MDS yang menggabungkan antara semua atribut yang dianggap sensitif pada dimensi masing-masing. Dalam analisis tersebut terdapat lima atribut yang memiliki nilai di atas 1,5 , yaitu ketersediaan peraturan daerah mengenai wisata bahari, sarana listrik, teknik pengolahan limbah, penyerapan tenaga kerja, dan daya dukung wisata untuk kategori wisata pantai. Kelima atribut tersebut merupakan faktor paling sensitif yang mendukung keberhasilan pengelolaan wisata bahari di Pulau Pari. Oleh karena itu, untuk mencapai pengelolaan yang terpadu dan berkelanjutan diperlukan peran serta masyarakat dan pemerintah untuk meningkatkan atribut-atribut yang dianggap sensitif dan menjadi pengungkit keberhasilan pengelolaan wisata bahari.

Pengelolaan wisata berkelanjutan dengan memadukan konsep ekowisata dan wisata bahari diyakini dapat menjadi alternatif dalam pengelolaan Pulau Pari. Hal ini bertujuan agar peran ekosistem sebagai atribut dalam dimensi ekologi dapat terakomodasi sehingga tercapai pengelolaan dengan titik berat keterpaduan pengelolaan semua dimensi.

\section{DAFTAR PUSTAKA}

Alder J, Zeller D, Pitcher T, Sumaila R. 2002. A method for evaluating marine protected area management. Coastal Management. 30: 121-131. https:// doi.org/10.1080/089207502753504661

Anderies JM, Jansen MA, Ostrom E. 2004. A Framework to Analyze The Robustness of SocialEcological Systems from An Institutional Perspective. Ecology and Society. 9(1): 18 [online] URL http:// www.ecologyandsociety.org/vol9/iss1/ art 18/. https://doi.org/10.5751/ES-00610-090118

Carpenter SR, Gundersom LH. 2001. Coping with colapse: ecological and sosial dynamics in ecosistem management. BioScience. 51: 451-457. https://doi.org/10.1641/0006-3568(2001)051 [0451:CWCEAS]2.0.CO;2

Fauzi A, Anna A. 2002. Evaluasi status keberlanjutan pembangunan perikanan: Aplikasi pendekatan rapfish (studi kasus perairan pesisir DKI Jakarta). Jurnal Pesisir dan Lautan. 4: 43-55.

Gossling S. 2001. The consequences of toursm for sustainable water use on tropical island: Zanzibar, Tanzania. Journal Envimanage. 61(2): 179-191. https://doi.org/10.1006/jema.2000.0403

Anwar R. 2011. Pengembangan dan keberlanjutan wisata bahari diwilayah pesisir dan pulau-pulau kecil di Kota Makassar. [Tesis]. Bogor (ID): Institut Pertanian Bogor.

Susilo SB. 2003. Keberlanjutan pembangunan pulaupulau kecil: Studi kasus Kelurahan Pulau Panggang dan Pulau Pari Kepulauan Seribu [disertasi]. Bogor (ID): Institut Pertanian Bogor.

Wong PP. 1991. Coastal Tourism in Southeas Asia. ICLARM. Education Series 13, 40p. Manila (PHL). 